\title{
Environmental detection of Batrachochytrium dendrobatidis in a temperate climate
}

\author{
Susan F. Walker ${ }^{1,2, *}$, Mario Baldi Salas ${ }^{2,5}$, Daniel Jenkins ${ }^{1}$, Trenton W. J. Garner ${ }^{2}$, \\ Andrew A. Cunningham ${ }^{2}$, Alex D. Hyatt ${ }^{3}$, Jaime Bosch ${ }^{4}$, Matthew C. Fisher ${ }^{1}$ \\ ${ }^{1}$ Department of Infectious Disease Epidemiology, Imperial College, St Mary's Campus, Norfolk Place, London W2 1PG, UK \\ ${ }^{2}$ Institute of Zoology, Regents Park, London NW1 4RY, UK \\ ${ }^{3}$ CSIRO Livestock Industries, Australian Animal Health Laboratory, 5 Port Arlington Road, Geelong, Victoria 3220, Australia \\ ${ }^{4}$ Museo Nacional de Ciencias Naturales, CSIC, José Gutiérrez Abascal, 2, 28006 Madrid, Spain \\ ${ }^{5}$ Present address: Tropical Diseases Research Program, Escuela de Medicina Veterinaria, Universidad Nacional Apartado \\ Postal 304-3000, Heredia, Costa Rica
}

\begin{abstract}
The aetiological agent of amphibian chytridiomycosis Batrachochytrium dendrobatidis is a primary cause of amphibian population declines. Current surveillance is based on the detection of $B$. dendrobatidis in its host but in vitro work suggests infective stages may survive in the abiotic environment for at least 3 mo. We describe here a surveillance system using filtration and quantitative PCR that can detect $B$. dendrobatidis in small $(<1$ l) volumes of water. After assessing the analytical sensitivity of the protocol for both water and sediment samples in the laboratory, we analyzed environmental samples from the Sierra de Guadarrama mountain range in Spain at locations associated with chytrid-related die-offs and at other sites across Spain. B. dendrobatidis was detected in samples from $64 \%$ of the ponds in the Sierra de Guadarrama and at 2 sites outside this region, showing that levels of amphibian exposure to $B$. dendrobatidis are spatially heterogeneous. In experimental microcosms, we detected $B$. dendrobatidis for up to $12 \mathrm{wk}$, though we found no evidence for an overall increase in biomass. Our results emphasise the need to further investigate the life cycle of $B$. dendrobatidis to more completely understand the epidemiology of this emerging pathogen.
\end{abstract}

KEY WORDS: Chytridiomycosis · Batrachochytrium dendrobatidis · Environmental surveillance · Filtration

\section{INTRODUCTION}

The aetiological agent of amphibian chytridiomycosis Batrachochytrium dendrobatidis is highly pathogenic to some amphibians and is one of the leading causes of global amphibian declines (Berger et al. 1998, Longcore et al. 1999, Pounds, 2006). The species is the only member of the phylum Chytridiomycota (Kingdom Fungi) that parasitizes a vertebrate host (Berger et al. 1998). The phylum is ecologically diverse but all species have an unwalled, flagellated zoospore that requires an aqueous medium for its dispersal and survival. Many chytrids have a resistant resting stage (Powell, 1993), but no such structure has been identi- fied for B. dendrobatidis (Morehouse et al. 2003). Zoospores produced by $B$. dendrobatidis infect the keratinized epidermis of amphibians and the mouthparts of anuran larvae, where they embed and form a zoosporangium. Detection of the zoosporangium in the host using either microscopic or molecular techniques has directed current surveillance strategies in amphibians (Berger et al. 1998, Garner et al. 2005).

Persistence of the organism in the environment in the absence of a host is not well understood. Batrachochytrium dendrobatidis can survive and remain infectious in sterile moist river sand for up to $12 \mathrm{wk}$ (Johnson \& Speare 2005). The organism can also grow on dead amphibian or snake skin and in liquid, or on 
solid culture media (Longcore et al. 1999). Thus, zoospores may persist in the environment for long periods of time and there may be hitherto undetected saprophytic stages with the ability to multiply. To better understand the biology and to analyze the epidemiology of $B$. dendrobatidis, a technique that can detect the pathogen in the environment and outside the host is urgently required.

Traditionally, zoosporic fungi are isolated with baiting methods using the bait a substrate for the fungus (Fuller 1987). This technique works well if the objective is to characterize an unknown fungal community, but is less effective if the objective is to isolate a particular species, especially if the target species is found at low densities or is poorly competitive. Previous attempts to obtain environmental samples of Batrachochytrium dendrobatidis by using traditional baiting techniques were not successful (Longcore et al. 1999, Livo, 2004).

The screening of DNA samples with environmental quantitative PCR provides a powerful tool to quantitatively detect water- and soil-borne pathogens, and its applications have been demonstrated for pathogenic Candida cells (Brinkman et al. 2003) and for Perkinsus marinus, a serious pathogen of the oyster Crassostrea virginica (Audemard et al. 2004). Here, we describe the development of a method that combines a simple, hand-held filtration system, a commercially available DNA extraction kit and a highly sensitive quantitative real-time PCR assay to detect $B$. dendrobatidis in small volumes $(<1$ l) of water. Our objectives were to (1) develop a sensitive, specific and quantitative tool to detect $B$. dendrobatidis in the environment, and (2) use this tool to assess spatial heterogeneity in levels of exposure of amphibians to $B$. dendrobatidis. The detection of $B$. dendrobatidis outside the amphibian host is vital for improvement of current surveillance measures and for more thorough study of fungus transmission at population and landscape levels.

\section{MATERIALS AND METHODS}

Minimum detection threshold for Batrachochytrium dendrobatidis. B. dendrobatidis was isolated from dead Alytes obstetricans samples collected in the Pyrenees mountains (isolate IA042, M. C. Fisher \& J. Bosch, www.spatialepidemiology.net/bd/maps) and cultured using standard techniques (Longcore et al. 1999). Zoospores were harvested from cultures and counted using a haemocytometer. These were used to prepare 10 -fold serial dilutions ( $1 \mathrm{ml}$ of solution contained 1000 , $100,10,1$ or 0.1 zoospore equivalents) for subsequent spiking experiments. Stocks were stored at $4^{\circ} \mathrm{C}$. Two autoclaved turbidity matrices were prepared using water and sediment from Regent's Canal and the Serpentine, London, UK. Turbidities corresponded to the natural state of the source water (percentage packed volume $[\mathrm{ppv}]=1.3 \%$ ) and to approximately $3 \times$ the natural state $(4 \% \mathrm{ppv})$. Turbidity values were measured after centrifugation $(1000 \times g$, room temperature, 10 $\mathrm{min}$ ) as the ppv of $10 \mathrm{ml}$ taken from a sample (Lowery et al. 2000). One $\mathrm{ml}$ of each culture dilution was added to a conical centrifuge tube containing $50 \mathrm{ml}$ of either $1.3 \%$ or $4 \%$ ppv solution.

Treatments $(\mathrm{n}=3)$ and an untreated control were included in each matrix. The contents of each flask were filtered through a cellulose nitrate filter membrane $(0.45 \mu \mathrm{m}$ pore size to capture $1-2 \mu \mathrm{m}$ zoospores; Berger et al. 1999) held in a dismountable $47 \mathrm{~mm}$ Swinnex filter holder (SX0004700, Millipore) using a $50 \mathrm{ml}$ syringe (XX1105005, Millipore) to collect and concentrate any Batrachochytrium dendrobatidis present. Rather than assessing various eluting strategies, we disrupted whole filter membranes (Brinkman et al. 2003, Coupland \& Johnson 2004). Following filtration, each membrane was placed into a Powerbead tube (Mobio Power Soil DNA extraction kit). These extraction kits were used due to their proven ability in removing environmental PCR inhibitors and for their high binding capacity of $20 \mu \mathrm{g}$ of DNA that limits saturation effects. The manufacturer's protocol was adopted with modifications. Specifically, Step 5 of the protocol was modified by homogenizing samples with a Minibeadbeater 8 (Biospec Products) at maximum speed for $2 \mathrm{~min}$, rather than using the recommended vortex for $10 \mathrm{~min}$. At the final step, $100 \mu \mathrm{l}$ of supernatant were collected, diluted $1: 10$ and stored at $-20^{\circ} \mathrm{C}$. The DNA dilutions were screened following the real-time quantitative Taqman assay of Boyle et al. (2004) in an Applied Biosystems 7300 Sequence Detection System (ABI 7300 SDS). High analytical sensitivity and specificity were achieved using primers ITS-1 Chyt and 5.8S Chytr, which target this multicopy region of the genome. A minor groove binder probe (ChytrMGB2) was used for detection. Samples were prepared in duplicate. Amplification standards of 0.1, 1, 10 and 100 zoospore equivalents and a negative control (distilled water) were included. The amplification standards were prepared from an isolate of known cell density (IA042 B. dendrobatidis, haemocytometer count). In the ABI 7300 SDS, amplification standards produced a standard curve from which quantities of $B$. dendrobatidis (as number of zoospore equivalents, i.e. ZE) in unknown samples were calculated (Fig. 1). A sample was identified as positive if clear log-linear amplification with a change in fluorescence $(\Delta \mathrm{Rn}>$ 0.1) was observed in both duplicates. Quantities were 


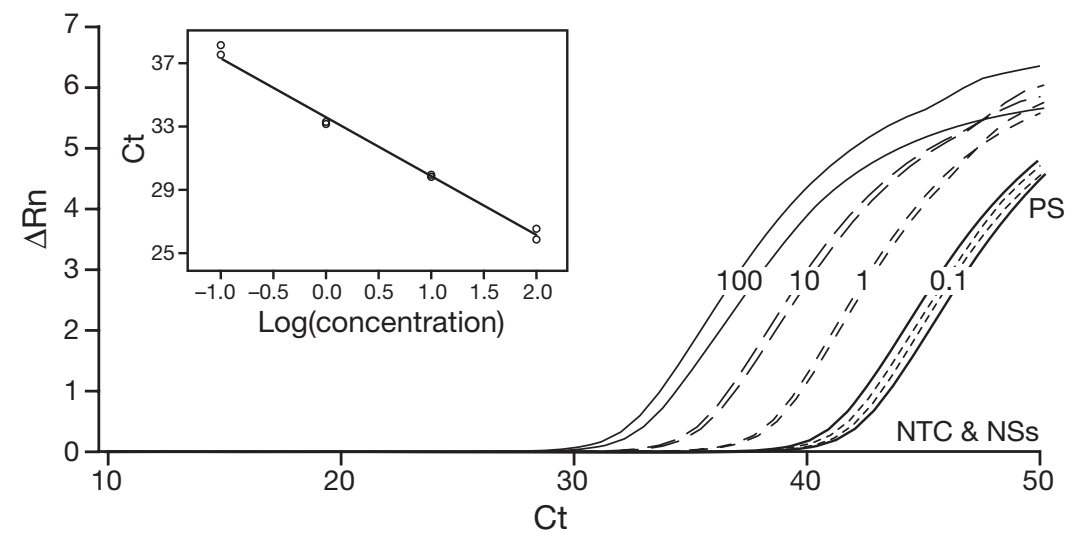

Fig. 1. Batrachochytrium dendrobatidis. Amplification plots of DNA extractions outside the core study site in the Sierra de Guadarrama. Change in fluorescence $(\Delta \mathrm{Rn})$ is plotted against cycle threshold number $(\mathrm{Ct})$. Standards $(0.1$, $1,10,100$ zoospore equivalents), the negative control (NTC), and the extractions corresponding to a positive sample (PS) and a negative sample (NS) are labelled. The multiple curves indicate duplicates for each sample. Inset: quantification standard curve. $\mathrm{Ct}=-3.7 \times \log (\mathrm{ZE})+34$, where $\mathrm{ZE}$ represents number of zoospore equivalents in the well

estimated according to a sample's cycle threshold (Ct) value, i.e. the cycle number at which $\Delta \mathrm{Rn}=0.1$.

Disinfection procedure for filter housing and syringe. Sodium hypochlorite is an effective agent for killing Batrachochytrium dendrobatidis (Johnson et al. 2003) and for denaturing nucleic acids (Suarez et al. 2003). The effectiveness of a disinfection procedure using $5 \%$ sodium hypochlorite (domestic bleach) was assessed in the laboratory prior to its use in the field. After flushing $75 \mathrm{ml}$ of a solution containing $1.5 \times 10^{6}$ zoospores through the filtration system, the filter housing and syringe were immersed in a $5 \%$ sodium hypochlorite solution for $5 \mathrm{~min}$. The components were then washed and flushed with tap water to remove any residues of sodium hypochlorite. On reassembling the filtration system, $75 \mathrm{ml}$ of distilled water were passed through a new membrane. The membrane was removed and the presence of $B$. dendrobatidis DNA was checked using the extraction and detection procedure described above.

Microcosm experiments. In 2005 and 2006, microcosms containing autoclaved and non-autoclaved pond sediment were established. In 2005, eight $5 \mathrm{~g}$ samples of sediment were inserted into $50 \mathrm{ml}$ centrifuge tubes. Half of the tubes were autoclaved thrice at $121^{\circ} \mathrm{C}$ for $60 \mathrm{~min}$, with intervals of $24 \mathrm{~h}$ at room temperature between sterilizations. Subsequently, 3 of the 4 tubes from each treatment (autoclaved/nonautoclaved) were spiked with $500 \mu \mathrm{l}$ of culture containing the equivalent of $1.5 \times 10^{6}$ zoospores $\mathrm{ml}^{-1}$. The remaining 2 tubes served as negative controls and were spiked with $500 \mu$ of uninoculated culture medium. The microcosms were incubated in a non-rotating, artificially lit, vented incubator at $18^{\circ} \mathrm{C}$ for $9 \mathrm{wk}$. After 0, 3, 7 and $9 \mathrm{wk}$ of incubation, the tubes were vortexed briefly and 3 samples of $0.25 \mathrm{~g}$ (wet weight) of sediment were collected. DNA was extracted from the sediment and amplified by quantitative PCR (qPCR) as described above. This experimental set-up was repeated in 2006 with the following amendments: (1) each treatment was replicated in triplicate, and (2) samples of sediment were collected at Weeks 0, 4, 8 and 12 .

Assessment of the technique in the field. The field study was conducted primarily in and around Peñalara Natural Park (768 ha, $40^{\circ} 50^{\prime} \mathrm{N}, 3^{\circ} 57^{\prime} \mathrm{W}$ ), an alpine region located between 1800 and $2200 \mathrm{~m}$ elevation in the Sierra de Guadarrama mountain range of central Spain (Fig. 2A). Mass mortality of Alytes obstetricans attributable to chytridiomycosis was first detected here in 1997 (Bosch et al. 2001) and all 9 amphibian species in the park have been infected by B. dendrobatidis (S. F. Walker, M. C. Fisher $\&$ J. Bosch unpubl. data). Peñalara contains over 250 bodies of water; some are ephemeral and others permanent, ranging in size from 0.3 to $6463 \mathrm{~m}^{2}$. The waters are slightly acidic $(\mathrm{pH}$ ) with low levels of conductivity $\left(<30 \mu \mathrm{S} \mathrm{cm}{ }^{-1}\right.$ at $25^{\circ} \mathrm{C}$ ) (Toro \& Granados 1999).

In July 2005, we sampled within the Sierra de Guadarrama at 42 sites for water and 52 sites for sediment. Water was collected within $10 \mathrm{~cm}$ of the edge of a pond and passed through the filter until the membrane was saturated. When streams flowed from pools, filtrations were conducted at the points of confluence to maximize representation of complete water bodies. Each membrane was folded twice with sterile forceps, with the 'capturing surface' facing inwards. The membranes were stored individually in $60 \mathrm{ml}$ sterile Nasco Whirlpak ${ }^{\mathrm{TM}}$ polyethylene bags, and kept on ice until frozen at $-20^{\circ} \mathrm{C}$. DNA was extracted and screened from these membranes. The relative density of Batrachochytrium dendrobatidis at each site was calculated from the estimated number of zoospores (as determined by quantitative PCR) and the volume of water filtered. To account for the 10 -fold dilution factor and the use of only $5 \mu \mathrm{l}$ per $100 \mu \mathrm{l}$ total extraction volume as a PCR template, the extracted zoospore equivalent $(\mathrm{EZE})$ was calculated as: $\mathrm{EZE}=\mathrm{ZE} \times 10 \times 20 . \mathrm{EZE}^{-1}$

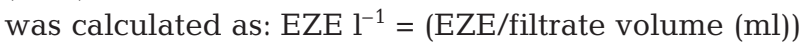
$\times 1000$. To reduce cross-contamination, the collecting and filtration system was cleaned in the field by immersion in a solution of $5 \%$ sodium hypochlorite for 
at least 5 min before and after each filtration. Additionally, prior to the start of a new filtration, the system was flushed 10 times with water from the new sample site.

Superficial sediment was collected from each water filtration site and from 8 additional ponds in which no water remained. Approximately $100 \mathrm{~g}$ of sediment was collected in conical centrifuge tubes and excess water was eliminated by decanting. Samples were stored in sterile Whirlpak polyethylene bags and kept on ice until frozen at $-20^{\circ} \mathrm{C}$. From each sample, $0.25 \mathrm{mg}$ (wet weight) was processed using a Mobio Power soil DNA extraction kit.

Additional filtrations were conducted from 29 other sites across Spain where amphibian populations have been tested for the presence of Batrachochytrium dendrobatidis (Fig. 2). These sites represent a diverse array of water bodies (lakes, streams, water troughs) across a broad altitudinal range.

Assessment of environmental PCR inhibitors. An internal positive control was used to assess evidence for PCR inhibition. Following the methodology of Hyatt et al. (2007), a VICTM labelled synthetic amplicon was used as an internal positive control (VICTM dye, Applied Biosystems No. 4308323). For a subset of samples, this internal positive control was included in one of each duplicate well as $1 \mu \mathrm{l} 10 \times$ Exo IPC mix and $0.5 \mu \mathrm{l} 50 \times$ Exo IPC DNA (Applied Biosystems). Environmental samples with Ct values significantly higher than a control were considered to be under the influence of PCR inhibition.

Statistical methods. Statistical analyses were conducted with the R software package (Version 2.2.1, The R Foundation for Statistical Computing). The Wilcoxon-Mann-Whitney test was used to test for significant differences in the recovery of DNA between the autoclaved and non-autoclaved microcosms at each time period. Significance was assessed at the 5\% level. In 2006, mean Ct values from the 3 samples collected in each tube were used in the analysis.

\section{RESULTS}

\section{Optimization of the technique and disinfection procedure}

The minimum detectable spike of one zoospore (0.9 genome equivalents) in $50 \mathrm{ml}$ of water was detected in both water matrices. At each concentration, the amount of DNA detected (as 1/Ct) was lower in the more-turbid water matrix (paired $t$-test, $\mathrm{p}<$ 0.005). No positive amplifications were obtained from membranes used in the apparatus post-disinfection showing that there was no carry-over of zoospores or of detectable Batrachochytrium dendrobatidis DNA.

\section{Persistence of Batrachochytrium dendrobatidis DNA in experimental microcosms}

In both years, Batrachochytrium dendrobatidis was detected for the entire duration of the experiment, except in the negative control microcosms. However, between the first and the last sampling period, recovery declined by up to and $>99 \%$ (Fig. 3). At all of the
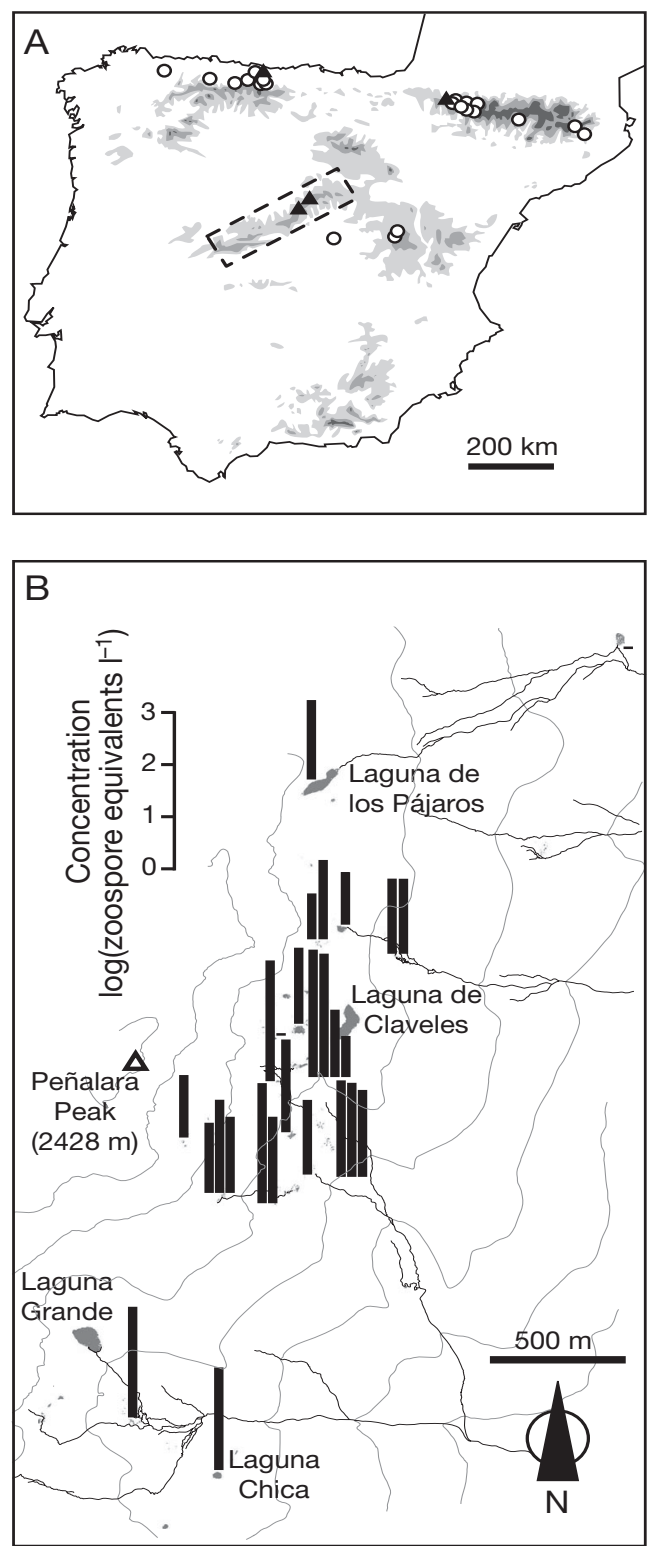

Fig. 2. Batrachochytrium dendrobatidis. (A) Locations of sampling sites in Spain. Sites positive $(\mathbf{\Delta})$ or negative $(O)$ for the fungus. Peñalara Natural Park is located within the Sierra de Guadarrama mountain range (box). (B) Sites within Peñalara Natural Park that tested positively for B. dendrobatidis. Bar charts show concentrations of zoospores at sites (as log zoospore equivalents $\mathrm{l}^{-1}$ ). Zoospore concentrations in samples of known filtrate volumes were calculated from amounts of DNA recovered from filters 


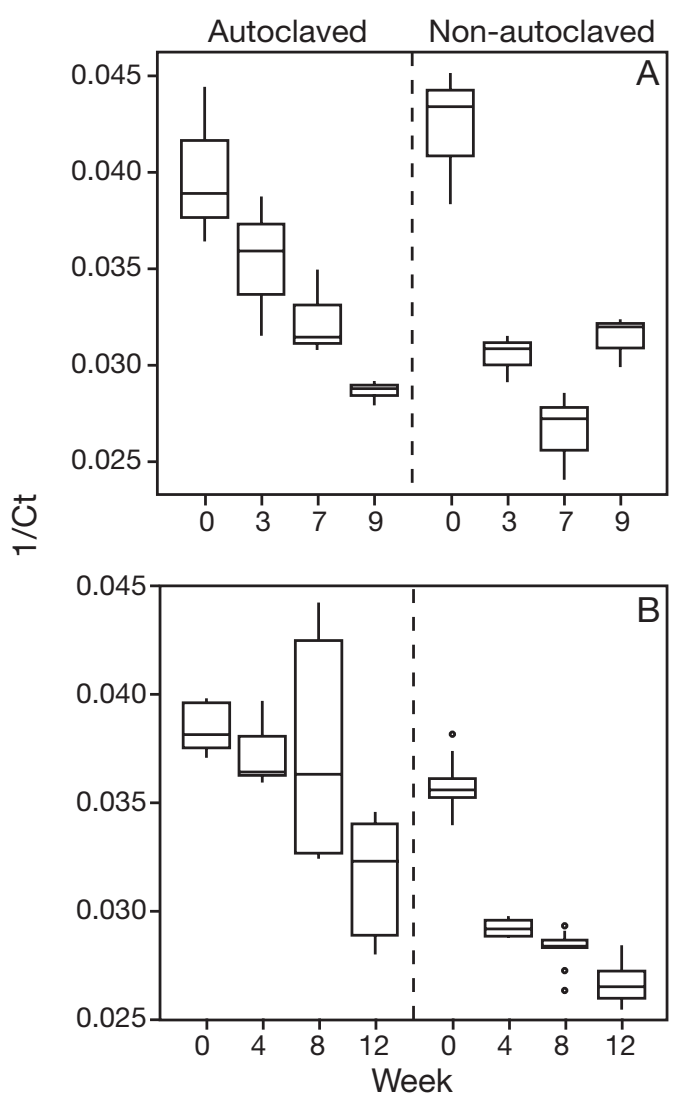

Fig. 3. Batrachochytrium dendrobatidis. Decrease in target DNA (increase in 1/cycle threshold, 1/Ct) plotted against week post-inoculation in (A) $2005(\mathrm{n}=3)$ and (B) $2006(\mathrm{n}=9)$; in both plots, numbers on the $x$-axis refer to weeks postinoculation. Treatment is autoclaving. Box and whisker plots show medians, interquartile ranges and min./max. values

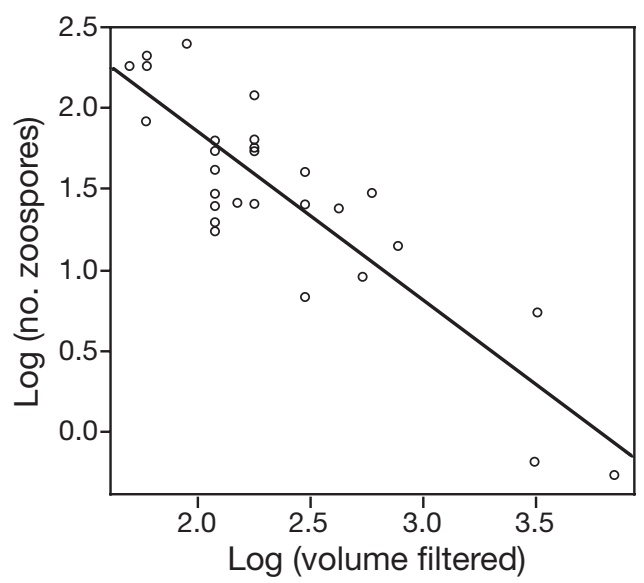

Fig. 4. Batrachochytrium dendrobatidis. Negative relationship between the volume $(\mathrm{ml})$ of filtered water and the concentration (no. $\mathrm{l}^{-1}$ ) of zoospores recovered on the filter; both variables log transformed. Surveillance sites are located within or in close proximity to Peñalara Natural Park (Sierra de Guadarrama) (see Fig. 2) time periods in 2006 and at 2 of the 4 sampling periods in 2005, the $\mathrm{Ct}$ values in the autoclaved microcosms were significantly lower (i.e. greater mass of B. dendrobatidis DNA) than those in the non-autoclaved microcosms (Wilcoxon-Mann-Whitney test, p < 0.05).

\section{Field detection of Batrachochytrium dendrobatidis in water and sediment}

With the exception of 4 water bodies, <1 1 of water was filtered at each site, and $<200 \mathrm{ml}$ were filtered at $>50 \%$ of the sites, reflecting the highly turbid nature of the waters. We detected Batrachochytrium dendrobatidis on $64 \%$ of the filters from ponds in the Sierra de Guadarrama. The estimated concentration of B. dendrobatidis at the positive sites varied from 0.5 to 262 zoospores $\mathrm{l}^{-1}$ (Fig. 2B), with a median of $31 \mathrm{l}^{-1}$, an interquartile range of 20 to $67 \mathrm{l}^{-1}$ and a SD of 70.5 zoospores. At Circo del Nevero, where there was an outbreak of chytridiomycosis at the time of sampling, we detected 67 zoospores $\mathrm{l}^{-1}$. A highly significant (linear regression adjusted $\mathrm{r}^{2}=0.75, F_{1,26}=82.02, \mathrm{p}<1 \times$ $10^{-8}$ ) negative relationship was found between the volume of water filtered (which is inversely related to turbidity) and the calculated concentration of $B$. dendrobatidis zoospores (Fig. 4), i.e. the more turbid the water, the higher the concentration of $B$. dendrobatidis.

Batrachochytrium dendrobatidis PCR products were not obtained from 48 of the 52 DNA extractions from sediment. For the remaining 4 samples, amplification occurred in only one of the replicate wells; we consider these 4 results to be indeterminate.

\section{Samples from outside the Sierra de Guadarrama mountain range}

Batrachochytrium dendrobatidis was detected in 2 of the 29 samples taken outside the Sierra de Guadarrama mountain range (Fig. 2A). One site was a water trough in Asturias where larvae of Alytes obstetricans have been found PCR-positive for $B$. dendrobatidis (S. F. Walker \& J. Bosch unpubl. data). The second site was a lake in the Pyrenees, Ibon Acherito, where mass mortalities of Alytes obstetricans have been observed (M. C. Fisher \& J. Bosch unpubl. data).

\section{Assessment of environmental PCR inhibitors}

Ct values corresponding to the amplification of the synthetic amplicon in the internal positive control showed no evidence of PCR inhibition in either the 
more or the less turbid artificial water matrices. In Peñalara, 3 of the 6 sediment samples screened with the internal positive control showed no evidence of PCR inhibition (i.e. Ct values were within 0.5 of the negative extraction control). One sediment sample was within 2 Cts of the negative extraction and 2 samples showed significant evidence of inhibition (in one of the samples the amplicon did not amplify and in the second there was a delay of 19 cycles). None of the 16 filter extractions from pond water screened with the IPC showed any evidence of PCR inhibition.

\section{DISCUSSION}

This study focused on developing a protocol for detecting Batrachochytrium dendrobatidis beyond the host. Monitoring of environmental stages of the fungus (i.e. outside the host) is essential for an understanding of its epidemiology because pathogens that cause high host-mortality are subject to densitydependent regulation and rarely cause extinction. This is because transmission chains in highly virulent pathogens with single host species tend to end when the basic reproduction number $R_{0}$ (average number of secondary cases of disease produced per typical primary case [Anderson \& May 1991]) is <1. However, if a pathogen has multiple hosts, or a reservoir of stages outside any biological host, values of $R_{0}>1$ can be maintained throughout the decline of a susceptible host population or species. Under these conditions, high levels of infection leading to extinction of susceptible hosts can occur if (1) the host species are highly endemic, i.e. spatially constrained, and (2) both withinand between-species transmission rates are high (Fenton \& Pedersen 2005). The high mortality rates suffered by amphibian species suggest that $B$. dendrobatidis may have a reservoir of stages outside the hosts (Daszak et al. 1999). Accordingly, we focused on methods for detecting fungi in the environment.

We found that Batrachochytrium dendrobatidis can be detected in the natural environment outside its amphibian host at densities of up to 262 zoospore equivalents $\mathrm{l}^{-1}$. However, we stress that our test does not distinguish DNA from cells, or actively reproducing cells from non-reproductive infective ones. The prevalence of $B$. dendrobatidis in certain areas of Spain (e.g. Peñalara Natural Park) is consistent with high values for $R_{0}$ and with the existence of large numbers of infectious zoospores. We hypothesize that the natural concentration of infectious zoospores predisposes susceptible amphibian populations to extirpation. We demonstrated high concentrations of B. dendrobatidis in regions undergoing mass mortalities. Therefore, there is an urgent need for further ecologi- cal studies of $B$. dendrobatidis to provide input data for current epidemiological models that consider transmission dynamics in multi- and single-host communities (Briggs et al. 2005).

The qPCR assay we employed is analytically sensitive to 0.1 zoospore equivalents and is highly specific for Batrachochytrium dendrobatidis (Boyle et al. 2004, Hyatt et al. 2007). The analytical specificity of the assay has been confirmed against 26 other Chytridiomycetes from 4 orders, viz. Chytridiales (Rhizophydium sp., Rhizophlyctis sp., Cladochytrium sp. and Chytriomyces sp.), Monoblepharidales (Gonapodya sp.), Blastocladiales (Allomyces macrogynus, Catenaria sp., Catenophlyctis sp.) and Spizellomycetales (Spizellomyces sp., Rhizophydium sp., Powellomyces sp.; Boyle et al. 2004, Hyatt et al. 2007). Further, our finding that positive environmental $\mathrm{qPCR}$ results correlate with known areas of infection is consistent with high diagnostic specificity.

Beyond Peñalara and the Sierra de Guadarrama mountain range, 2 of 29 water bodies tested were positive for Batrachochytrium dendrobatidis. One of these was a water trough in Asturias where larvae of Alytes obstetricians infected by $B$. dendrobatidis were present at the time of sampling (S. F. Walker \& J. Bosch unpubl. data) and the other corresponded to a lake in the Pyrenees from which chytrid-related mass mortalities of A. obstetricans have been detected. Because we screened amphibians at all the filtration sites (S. F. Walker \& J. Bosch unpubl. data), we know that B. dendrobatidis is present at some sites that tested negative for the fungus in our molecular screening of filtered water. At these sites, the infection load in the environment may be lower than the detection threshold of our test, and/or micro-scale spatial and temporal heterogeneity may be preventing detection.

The significant association between the concentration of Batrachochytrium dendrobatidis and the relative turbidity of the waters in the Sierra de Guadarrama (Fig. 4) suggests that more complex water matrices may favor the survival of this fungus. If turbidity is a proxy for biological activity, this relationship is counterintuitive to our finding that the density of $B$. dendrobatidis was almost always consistently higher in the autoclaved than in the non-autoclaved microcosms. Thus, as in other aquatic microbial communities, species composition and competitive interactions may have a stronger regulatory effect on the growth dynamics of $B$. dendrobatidis than richness per se. The regulatory potential of the biotic environment will itself be modified by the abiotic environment, 2 effects that are difficult to disentangle in the complex matrix of water bodies in Peñalara. Notably, the absence of amplifiable $B$. dendrobatidis-DNA in the superficial sediment of ponds suggests that physico-chemical con- 
ditions limit the survival of $B$. dendrobatidis. Given that 3 of 6 sediment samples screened using the IPC showed no evidence of PCR inhibition, it seems unlikely that inhibitors in the sediment can completely explain the absence of $B$. dendrobatidis.

Previous work has suggested that Batrachochytrium dendrobatidis may have a naturally occurring saprophytic stage. The species may survive and remain infectious in sterile, autoclaved lake water for up to 7 wk post-inoculation (Johnson et al. 2003) and in sterile moist river sand ( $\mathrm{pH}$ 5.8) for at least $12 \mathrm{wk}$ (Johnson $\&$ Speare 2005). In addition to growth in or on culture media (Longcore et al. 1999), the organism also can grow on dead amphibian and snake skin, dead algae, insect exoskeletons and feathers (Johnson \& Speare 2005). Despite its sensitivity to desiccation, B. dendrobatidis also can survive on feathers that have been dried for 1 to $3 \mathrm{~h}$ (Johnson \& Speare 2005).

Although Batrachochytrium dendrobatidis is keratinophilic (Daszak et al. 1999), the fact that not all chytrid species are dependent on a single substrate for either attachment or metabolism (Sparrow 1960), together with the aforementioned laboratory and field studies, suggests that $B$. dendrobatidis may have a more complex epidemiological profile than would be expected for a pathogen dependent upon only amphibian hosts. The detection of $B$. dendrobatidis in small volumes of filtered water certainly supports this hypothesis. However, there was no consistent increase in biomass in the microcosms, demonstrating clear limits to the ecological envelope within which survival and growth are possible.

Numerous other ecological factors may affect abundance of Batrachochytrium dendrobatidis in the environment. The relatively low turnover rate in the waters of Peñalara may allow an increase in the concentration of cells, facilitating detection (by molecular technology) and the formation of significant abiotic reservoirs of zoospores outside the host animals. Further, the concentrations of $B$. dendrobatidis that we recorded in 2005 may have been particularly high as a result of abnormally low water levels within the park; 2005 was the driest year recorded since record keeping began in 1947 (see: www.inm.es). The levels of B. dendrobatidis in riparian habitats are expected to be lower than in the ponds of Peñalara due to continuous flushing of the system. Hence, environmental surveillance of $B$. dendrobatidis may demand a system that can process larger water volumes than we have described here.

The actual relationship between the DNA level detected and the number of viable cells present remains unknown. Extracellular DNA bound to sediment, for example, may be physically protected from nucleases. In contrast to DNA and rRNA, mRNA is turned over rapidly within cells, typically with a half life of only a few minutes, and its presence has been correlated with cell viability (Sheridan et al. 1998). Hence, the use of mRNA in reverse transcriptase PCRs enables both the symptomatic and presymptomatic detection of viable fungal pathogens in plants (Gough \& Lee 1985, McMaugh \& Lyon 2003) and we aim to investigate cell viability using Batrachochytrium dendrobatidis-specific probes to the mRNA of a constitutively expressed gene such as beta tubulin (Yan \& Liou 2006) or RNA polymerase RPB2.

Over 8 yr have passed since Batrachochytrium dendrobatidis was first described (Berger et al. 1998, Longcore et al. 1999). Although the implications of saprophytic nutrition in this species were highlighted in initial publications (Daszak et al. 1999, Speare 2001 ), the prevailing view today is that $B$. dendrobatidis is an amphibian-specific pathogen. In the natural environment, the survival and reproduction of portions of the organism's life cycle that are unrelated to the amphibian host remain unexplored. If, as is the case with many other chytrid species, $B$. dendrobatidis has a more complex biology than is currently appreciated (and hence a more complex epidemiological profile) the transmission parameters used in current theoretical mathematical models will not accurately reflect population dynamics and might even misguide conservation efforts. Quantitative environmental diagnostic tools such as those described here are essential for undertaking spatial and temporal surveys required for gaining a more complete understanding of the environmental reservoirs of $B$. dendrobatidis and the ecological constraints determining survival.

Acknowledgements. We thank the Director and employees of Peñalara Natural Park and the Consejerias de Medio Ambiente of Madrid, Asturias, Castilla la Mancha, Cataluña and Aragon for their assistance with this study. This research was supported by the National Environment Research Council (NER/A/S/2002/00832) and the Fundación BBVA .

\section{LITERATURE CITED}

Anderson RM, May RM (1991) Infectious diseases of humans. Oxford University Press, Oxford

Audemard C, Reece KS, Burreson EM (2004) Real-time PCR for detection and quantification of the protistan parasite Perkinsus marinus in environmental waters. App Environ Microbiol 70:6611-6618

Berger L, Speare, R, Daszak P, Green DE and 10 others (1998) Chytridiomycosis causes amphibian mortality associated with population declines in the rain forests of Australia and Central America. Proc Natl Acad Sci USA 95: 9031-9036

Berger L, Speare R, Kent A (1999) Diagnosis of chytridiomycosis in amphibians by histologic examination. Zoos' Print J 15:184-190

Bosch J, Martínez-Solano I, García-París M (2001) Evidence of a chytrid fungus infection involved in the decline of the 
common midwife toad (Alytes obstetricans) in protected areas of central Spain. Biol Conserv 97:331-337

Boyle DG, Boyle DB, Olsen V, Morgan JAT, Hyatt AD (2004) Rapid quantitative detection of chytridiomycosis (Batrachochytrium dendrobatidis) in amphibian samples using real-time Taqman PCR assay. Dis Aquat Org 60:141-148

Briggs C, Vredenburg VT, Knapp RA, Rachowicz LJ (2005) Investigating the population-level effects of chytridiomycosis: an emerging infectious disease of amphibians. Ecology 86:3149-3159

Brinkman NE, Haugland RA, Wymer LJ, Byappanahalli M, Whitman RL, Vesper SJ (2003) Evaluation of a rapid, quantitative real-time PCR method for enumeration of pathogenic Candida cells in water. Appl Environ Microbiol 69:1775-1782

Coupland K, Johnson B (2004) Geochemistry and microbiology of an impounded subterranean acidic water body at Mynydd Parys, Anglesey, Wales. Geobiology 2:77-86

Daszak P, Berger L, Cunningham AA, Hyatt AD, Green DE, Speare R (1999) Emerging infectious diseases and amphibian population declines. Emerg Infect Dis 5:735-748.

Fenton A, Pedersen AB (2005) Community epidemiology framework for classifying disease threats. Emerg Infect Dis 11:1815-1821

Fuller MS, Jaworski A (eds) (1987) Zoosporic fungi in teaching and research. Southeastern Publishing, Athens, GA

Garner TWJ, Walker S, Bosch J, Hyatt AD, Cunningham AA, Fisher MC (2005) Chytrid fungus in Europe. Emerg Infect Dis 11:1639-1641

Gough FJ, Lee, TS (1985) Moisture effects on the discharge and survival of conidia of Septoria tritici. Phytopathology 75:180-182

Hyatt AD, Boyle DG, Olsen V, Boyle and 11 others (200) Diagnostic assays and sampling protocols for the detection of Batrachochytrium dendrobatidis. Dis Aquat Org 73: 175-192

Johnson M, Speare R (2005) Possible modes of dissemination of the amphibian chytrid Batrachochytrium dendrobatidis in the environment. Dis Aquat Org 65:181-186

Johnson ML, Berger L, Philips L, Speare R (2003) Fungicidal effects of chemical disinfectants, UV light, desiccation and heat on the amphibian chytrid Batrachochytrium dendrobatidis. Dis Aquat Org 57:255-260

Livo LJ (2004) Snakeskin as a bait for Batrachochytrium dendrobatidis. In: Jackson T (ed) Report on the status and conservation of the boreal toad Bufo boreas boreas in the

Editorial responsibility: Julie Bebak,

Auburn, Alabama, USA southern Rocky Mountains. Colorado Division of Wildlife, Denver, CO, p 59

Longcore JE, Pessier AP, Nichols DK (1999) Batrachochytrium dendrobatidis gen. et sp. nov., a chytrid pathogenic to amphibians. Mycologia 91:219-227

Lowery CJ, Moore JE, Millar BC, Burke DP, McCorry KAJ, Crothers E, Dooley JSG (2000) Detection and speciation of Cryptosporidium spp. in environmental water samples by immunomagnetic separation, PCR and endonuclease restriction. J Med Microbiol 49:779-785

McMaugh SJ, Lyon BR (2003) Real-time quantitative RT-PCR assay of gene expression in plant roots during fungal pathogenesis. Biotechniques 34:982-986

Morehouse EA, James TY, Ganley ARD, Vilgaly R, Berger L, Murphy PJ, Longcore JE (2003) Multilocus sequence typing suggests the chytrid pathogen of amphibians is a recently emerged clone. Mol Ecol 12:395-403

Pounds J (2006) Widespread amphibian extinctions from epidemic disease driven by global warming. Nature 439: 161-167

Powell MJ (1993) Looking at mycology with a Janus face - a glimpse at Chytridiomycetes active in the environment. Mycologia 85:1-20

Sheridan GEC, Masters CI, Shallcross JA, Mackay BM (1998) Detection of mRNA by reverse transcription-PCR as an indicator of viability in Escherichia coli cells. Appl Environ Microbiol 64:1313-1318

Sparrow FK (1960) Aquatic phycomycetes. The University of Michigan Press, Ann Arbor, MI

Speare R (2001) Developing management strategies to control amphibian diseases: decreasing the risks due to communicable diseases. School of Public Health and Tropical Medicine, James Cook University, Townsville

Suarez D, Spackman E, Senne D, Bulaga L, Welsch, AC, Froberg K (2003) The effect of various disinfectants on detection of avian influenza virus by real time Rt-PCR. Avian Dis 47:1091-1095

Toro M, Granados I (1999) Los humedales del Parque Natural de Peñalara. In: Navalon L, Prieto D (eds) Primeros encuentros cientificos del Parque Natural de Peñalara y del Valle del Paular. Consejeria de Medio Ambiente, Direccion General del Medio Natural, Madrid, p 127-139

Yan HZ, Liou RF (2006) Selection of internal control genes for real-time quantitative RT-PCR assays in the oomycete plant pathogen Phytophthora parasitica. Fungal Genet Biol 43:430-438

Submitted: May 14, 2007; Accepted: July 18, 2007

Proofs received from author(s): September 10, 2007 